\title{
The Effectivesness Meaning of Life and Antiretroviral Therapy (Metart) Modul to Improve Antire to Viral Therapy Adherence among Newly Diagnosed HIV/AIDS: Pre Intervention Survey
}

\author{
Yafi Sabila Rosyad ${ }^{1}$, Firmina Theresia Kora ${ }^{2}$, Rika Monika ${ }^{3}$, \\ Salis Miftahul Khoeriyah ${ }^{4}$, I. PutuJuni Andika ${ }^{5}$ \\ ${ }^{1}$ Asist. Prof., Dept. of Mental Health in Nursing, STIKes Yogyakarta, Indonesia, Rosyad, ${ }^{2}$ Asist. Prof. Dept of Basic \\ Science and Fundamental of Nursing, STIKes Yogyakata, Indonesia, ${ }^{3}$ Dept. of Community in Nursing, STIKes \\ Yogyakarta, Indonesia, ${ }^{4}$ Dept. of Pediatric in Nursing, STIKes Yogyakarta, Indonesia, ${ }^{5}$ Dept. of Basic Science and \\ Fundamental of Nursing, STIKes Yogyakata, Indonesia
}

\begin{abstract}
Adherence to ART is the primary determinant of viral suppression. Adherence of at least $95 \%$ is needed for optimal suppression. One of relationship with HAART is meaning in life. This study aimed at assessment meaning in life and adherence antiretroviral therapy before intervention about METART book.

This method use descriptive statistic analysis to explain social demographic, meaning in life, and adherence antiretroviral therapy.

The Result: Characteristics gender people new living with HIV/AIDS this study is $75,6 \%$ is Male with $38,5 \%$ homosexual. The age range of respondents is in the adult $(65,4 \%)$. Single merital status is $74.4 \%$. The total respondent with ARV medication is $30.8 \%$ under one year. $74.4 \%$ has meaningful life but $65,4 \%$ respondent has lack adherence ARV.
\end{abstract}

Conclusion: This research get data pre intervention METART modul about demographic, meaning in life, and adherence ARV.

Keywords: Adherence ART, meaning of life, HIV/AIDS.

\section{Introduction}

Adherence to ART is the primary determinant of viral suppression and the risk of transmission it decreases the viral replication and viral load which in turn preserves the CD4 level, decreases the progress of AIDS, and reduces deaths ${ }^{(1)}$. Adherence of at least $95 \%$ is needed for optimal suppression ${ }^{(2,3)}$. Antiretroviral

\footnotetext{
Coressponding Author

Yafi Sabila Rosyad

Asist. Prof., Dept. of Mental Health in Nursing, STIKes

Yogyakarta, Indonesia, Rosyad

e-mail: rosyad2yafi@gmail.com
}

therapy has an impressive clinical effect in that WHO has a target that $90 \%$ of People Living with HIV/ AIDS (PLWHA) already underwent ART by 2016, but the target realization is only $53 \%$. From year to year, PLWHA who undergo antiretroviral therapy is increasing. In 2016, there are 19.5 million or about 53\% of the total number of PLWHA, and in mid-June 2017 the number has progressed to 20.9 million or about $56.9 \%$ of the total number of PLWHA ${ }^{(3,4)}$. Although adherence is important to the outcomes of therapy(5).

Out of 231 respondents in Nepal, 87.4\% (95\% CI: $83.2-91.6 \%$ ) of them had an optimal adherence level and $12.6 \%$ of the respondents had an adherence level less than the opti-mal within the last month. i.e. $87.4 \%$ of the respondents' attained $95 \%$ adherence to 
prescribed ART regimen ${ }^{(3)}$. Results of the evaluation of adherence to ART in Brazil using CEAT-VIH indicated that $50 \%(109 / 220)$ of the patients presented good adherence, 36\% (79/220) presented strict adherence, and $14 \%(32 / 220)$ presented low adherence ${ }^{(6)}$. Based on the results research in Iran, 30.4\% (65) of patients were non-adherent and $69.6 \%$ (149) showed good adherence to their medication protocols. The most important reason for discontinuation of medication was the patients' unknown personal reasons $(n=60,61.2 \%)$, from the nonadherence group $^{(7)}$. Many determinant factors to present non-adherence; quality of life, distress psychology, meaning in life, self-efficacy, peer group, economy, health worker, stigma, motivation, gender ${ }^{(3,7-11)}$.

Effect of non-adherence ARV increases mortality and morbidities. HIV/AIDS has effect to biological, psychological, social, and spiritual. Thus, prevention of co-morbidities, improving knowledge through health education. Psychoeducation should be conducted at the initial evaluation to reduce negative beliefs regarding antiretroviral therapy Assessment of anxiety and depression symptoms should be done throughout therapy as both psychological conditions are associated with patient adherence, success of treatment, and ultimately with patients' quality of life. This study researcher will be increasing of meaning in life to increasing adherence ARV people living with HIV/AIDS.

\section{Material and Method}

The study protocol and consent procedures were reviewed and approved by the Institutional Review Boards of Sekolah Tinggi Ilmu Kesehatan Ngudia Husada Madura with number of ethical clearance 709/ KEPK/STIKES-NHM-/EC/IX/2020. In accordance with the approved protocol, written informed consent was obtained from all study participants prior to data collection. This study is assessment pre intervention of meaning in life and antiretroviral therapy (METART) to promoting adherence antiretroviral therapy. Researcher use meaning in life questionnaire Indonesian version ${ }^{(12)}$ and Morisky 8 -scale ${ }^{(13)}$ to assessment meaning in life and adherence antiretroviral therapy. Data analysis, descriptive statistic ${ }^{(14-16)}$ were used to determine statistical differences in demographic variables (i.e., gender, education, marital status, CD4 status, Viral load status, Sexual orientation), meaning in life and adherence ART.

\section{Result and Discussion}

Demographic Characteristics: A total of 78 PLWHAs were invited to participate in the study. Demographic Characteristics Are gender, sexual orientation, age, education level, merital status, ARV medication, CD4 status, and viral load status (Table 1).

Table 1.1: Demographic Characteristics people new living with HIV/AIDS $n=78$

\begin{tabular}{|c|c|c|}
\hline Demographic data & Frequency (n) & Percent (\%) \\
\hline \multicolumn{3}{|l|}{ Gender } \\
\hline Female & 16 & 20.5 \\
\hline Male & 59 & 75.6 \\
\hline Other & 3 & 3.8 \\
\hline Total & 78 & 100 \\
\hline \multicolumn{3}{|l|}{ Sexual-orientation } \\
\hline Heterosexual & 26 & 33.3 \\
\hline Homosexual & 30 & 38.5 \\
\hline Bisexual & 15 & 19.2 \\
\hline Other & 7 & 9 \\
\hline Total & 78 & 100 \\
\hline \multicolumn{3}{|l|}{ Age } \\
\hline Adolescent & 24 & 30.8 \\
\hline Adult & 51 & 65.4 \\
\hline Elderly & 3 & 3.8 \\
\hline Total & 78 & 100 \\
\hline \multicolumn{3}{|l|}{ Education-level } \\
\hline $\begin{array}{l}\text { Middle-elementary } \\
\text { school }\end{array}$ & 7 & 9 \\
\hline High school & 50 & 64.1 \\
\hline Undergraduate & 20 & 25.6 \\
\hline Postgraduate & 1 & 1.3 \\
\hline Total & 78 & 100 \\
\hline \multicolumn{3}{|l|}{ Merital status } \\
\hline Sigle & 58 & 74.4 \\
\hline Meried & 16 & 20.5 \\
\hline $\begin{array}{l}\text { Window/windower/ } \\
\text { divorce }\end{array}$ & 4 & 5.1 \\
\hline Total & 78 & 100 \\
\hline \multicolumn{3}{|l|}{ ARV-Medication } \\
\hline $0-6$ months & 18 & 23.1 \\
\hline 7-12 months & 24 & 30.8 \\
\hline 13-18 months & 17 & 21.8 \\
\hline 19-24 months & 19 & 24.4 \\
\hline Total & 78 & 100 \\
\hline
\end{tabular}




\begin{tabular}{|l|c|c|}
\hline Demographic data & Frequency (n) & Percent (\%) \\
\hline Cd4-Status & & \\
\hline$<200$ & 13 & 16.7 \\
\hline $200-300$ & 13 & 16.7 \\
\hline $300-400$ & 20 & 25.6 \\
\hline $400-500$ & 14 & 17.9 \\
\hline$>500$ & 11 & 14.1 \\
\hline I don't know & 7 & 9 \\
\hline Total & $\mathbf{7 8}$ & $\mathbf{1 0 0}$ \\
\hline Viral load status & & \\
\hline Detections & 16 & 20.5 \\
\hline Un-detections & 22 & 28.2 \\
\hline I don't know & 40 & 51.3 \\
\hline Total & $\mathbf{7 8}$ & $\mathbf{1 0 0}$ \\
\hline
\end{tabular}

life so that the feeling of happiness will emerge, on contrary it can lead one to a meaningless empty life if they unsuccessful ${ }^{(23-25)}$. Meaning of life had a different function for each individual, but according to Mackenzie \& Baumeister (2014), the function of meaning in life could be divided into three function themes ${ }^{(26)}$. The first function was to help someone in recognizing and discussing signs and patterns in the environment. The second function was for communication. The third function was for self-control. The meaning of life according to Starck (2014), was said to be the phase where a person reached his life goal ${ }^{(27)}$. The meaning of life have correlations with adherence ARV ${ }^{(11)}$.

Table 2: Meaning of life people living with HIV/ AIDS $n=78$

Characteristics gender people new living with HIV/ AIDS this study is $75,6 \%$ is Male with $38,5 \%$ homosexual. Homosexual is romantic sexual attraction, behavior with same $\operatorname{sex}^{(17)(18)(19)}$. The age range of respondents is in the adult $(65,4 \%)$ age range which is above $25-45$ where this age is a productive to developmental task of choosing a job and marriage. This time is also a time to build the peak structure of life ${ }^{(20)}$. Siglemerital status is $74.4 \%$. the total respondent with ARV medication is $30.8 \%$ under one year. Almost respondent have CD4 under 500, a normal CD4 cell count is about 500 until 1.500 cells/ $\mathrm{mm}^{\wedge} 3$. Clinicians use this test to monitor the destruction of CD4 cells, and it also monitors the effectiveness of the antiretroviral treatment (ART). For a physician, the CD4 cell count has become the best indicator of disease progression and is used to stage disease and guide medical therapy. Per the Center for Disease Control and Prevention (CDC), one of the indications for the diagnosis of AIDS is when CD4 cell count drops below 200 cells $/ \mathrm{mm}^{\wedge} 3$. The decline of CD4 T cells can lead to opportunistic infections, and it increases mortality. The results of a viral load test are described as the number of copies HIV RNA in a milliliter of blood, when somebody has undetected of viral load is described if the copies of HIV RNA of blood in very low and its good for healthy ${ }^{(10,11)}$.

Meaning of Life: The result showed $74.4 \%$ people with newly diagnosed HIV/AIDS had meaningful life (Tabel 2).

Meaning of life is comprehended from every event that occurred and experienced both pleasant and distressing events. It will bring a person into a meaningful

\begin{tabular}{|l|c|c|}
\hline Meaning of Life & Frequency (n) & Percent (\%) \\
\hline Meaningfull life & 58 & 74.4 \\
\hline Low meaning in life & 20 & 25.6 \\
\hline Total & 78 & 100 \\
\hline
\end{tabular}

Adherence antiretroviral therapy:

Table 3: Adherence antiretroviral therapy $n=78$

\begin{tabular}{|l|c|c|}
\hline $\begin{array}{l}\text { Adherence } \\
\text { antiretroviral therapy }\end{array}$ & Frequency (n) & Percent (\%) \\
\hline High adherence & 27 & 32.6 \\
\hline Middle adherence & 26 & 33.3 \\
\hline Low adherence & 25 & 32.1 \\
\hline Total & $\mathbf{7 8}$ & $\mathbf{1 0 0}$ \\
\hline
\end{tabular}

From the research results obtained that 59 respondents or $57.8 \%$ were adherence to antiretroviral therapy and the rest did not comply as much as 43 respondents or $42.2 \%$. This level of adherence was seen from the accuracy of the dosage and the frequency of timeconsuming ARV. The non-adherence of respondents based on the questionnaires due to forgetting to take the drugs by $26.5 \%$ and difficult to remember to consume the drugs by $28.4 \%$.

ART treatment has the potential to reduce mortality and morbidity that associated with HIV infection, and improve the quality of life ${ }^{(28,29)}$. A person is said to be adherent in undergoing an optimal antiretroviral therapy if ( $>95 \%)$ never forgets to take the drug, but it is recommended that the adherence is $(100 \%)$. According toBangsberg, Kroetz, \& Deeks, (2007), ART adherence should be observed to discern the compliance level of the 
treatment, as some studies indicate that with treatment adherence of (95\%) or more indicates the effectiveness of antiretroviral therapy ${ }^{(30)}$, but on adherence $(75 \%)$ shows a rise of viruses with retention against drugs ${ }^{(31)}$. Some patients fail to maintain ART adherence ${ }^{(32)}$. Optimal ART adherence was significantly associated with being virally suppressed ${ }^{(1,7,9,10)}$.

Many factors to associate ART is motivation on the relationship between HIV stigma and ART adherence ${ }^{(10)}$.

\section{Conclusion}

Characteristics of participants ages from 18 to 54 years, $75,6 \%$ identified as Male, $64,1 \%$ had completed high school, 74,4\% sigle, $38,5 \%$ identified as homosexual and $30,8 \%$ pastisipants had ART medication under one year. The participant reported $74,4 \%$ was having meaningful life and 65,4\% reposted had lacked ART Adherence.

Conflict of Interest: The Authors declare that there is no conflict of interest.

Acknowledgments The and Source of Funding: We thanks to the staff from NGOs Victory Plus Yogyakarta for the support and dedicated to all the participants who made this study posibble. This work was funded by Ministry of Research and Technology/ Nasional Research and Innovation Agency of the Republic of Indonesia.

Ethical Clearance: This research is not conflict of interests with ethical clearance No;709/KEPK/STIKESNHM/EC/IX/2020.

\section{References}

1. Molla AA, Gelagay AA, Mekonnen HS, Teshome DF. Adherence to antiretroviral therapy and associated factors among HIV positive adults attending care and treatment in University of Gondar Referral Hospital, Northwest Ethiopia. BMC Infect Dis. 2018;18(1):1-8.

2. Soares R de CA, de Brito AM, Lima K, Lapa TM. Adherence to antiretroviral therapy among people living with HIV/AIDS in Northeastern Brazil: A cross-sectional study. Sao Paulo Med J. 2019;137(6):479-85.

3. Neupane S, Dhungana GP, Ghimire HC. Adherence to antiretroviral treatment and associated factors among people living with HIV and AIDS in CHITWAN, Nepal. BMC Public Health. 2019;19(1):1-9.

4. WHO. World Health Statistics 2017 Monitoring Health For the SGDs [Internet]. France: WHO Press; 2017. 1-103 p. Available from: http://apps. who.it/iris

5. Byrd KK, Hou JG, Hazen R, Kirkham H, Suzuki S, Clay PG, et al. Antiretroviral Adherence Level Necessary for HIV Viral Suppression Using Real-World Data. J Acquir Immune Defic Syndr. 2019;82(3):245-51.

6. Oliveira L da S, Caixeta LM, Martins JLR, Segati $\mathrm{KD}$, Moura RS, Daher MC, et al. Adherence to antiretroviral therapy and correlation with adverse effects and coinfections in people living with HIV/ AIDS in the municipality of Goiás State. Rev Soc Bras Med Trop. 2018;51(4):436-44.

7. Motazedian N, Sayadi M, Firoozbakhtian A. Nonadherence to anti-retroviral medication in shiraz, 2014: A cross sectional study. Afr Health Sci. 2018;18(2):384-93.

8. Betancur MN, Lins L, Oliveira IR de, Brites C. Quality of life, anxiety and depression in patients with HIV/AIDS who present poor adherence to antiretroviral therapy: a cross-sectional study in Salvador, Brazil. Brazilian J Infect Dis [Internet]. 2017;21(5):507-14. Available from: http://dx.doi. org/10.1016/j.bjid.2017.04.004

9. Kim J, Lee E, Park BJ, Bang JH, Lee JY. Adherence to antiretroviral therapy and factors affecting low medication adherence among incident HIV-infected individuals during 2009-2016: A nationwide study. Sci Rep [Internet]. 2018;8(1):1-8. Available from: http://dx.doi.org/10.1038/s41598-018-21081-x

10. Roman S, Altice FL, Copenhavera MM. HIVRelated Stigma, Motivation to Adhere to Antiretroviral Therapy, and Medication Adherence among HIV-Positive Methadone-Maintained Patients. Physiol Behav. 2018;176(1):139-48.

11. Rosyad YS, Malini H, Sarfika R. The association between meaning in life and adherence to antiretroviral therapy (Art) of hiv-seropositive within men who have sex with men (msm); mixed method. Indian J Public Heal Res Dev. 2019;10(10):1333-7.

12. Rosyad YS, Malini H, Sarfika R. Validity and reliability the meaning in life questionnaire (MLQ); Men who have sex with men at west Sumatera 
Indonesia. Ris Inf Kesehat. 2019;8(1):16-21.

13. Morisky DE, Green LW, Levine DM. Concurrent and Predictive validity of a self-reported measure of medication adherence. Med Care. 1986;24:6774.

14. Moleong LJ. Metodologi Penelitian Kualitatif. Bandung: PT Remaja Rosdakarya; 2011.

15. Creswell J. Research design Pendekatan metode kuantatif, kualitatif, dan campuran. 1st ed. Yogyakarta: Pustaka Pelajar; 2016.

16. Teddie C, Tashakkori A. Foundations of Mixed Method Research : Integrating quantitative and Qualitative Approache in the Social and Behavioral Sciences. I. California: SAGE Publications; 2009.

17. Rosyad YS. Characteristic men who love sex with men HIV+ in GOs Taratak Jiwa hati West Sumaera Indonesia. Paeipex Indian Joaurnal Res. 2018;7(8):144-5.

18. Oetomo D. Memberi Pada Suara yang Bisu. Kedua. Gusmian I, editor. Yogyakarta: Pustaka Marwa; 2003.

19. Carroll. Sexuality Now Embracing Diversity. Belmont: Wadsworth Cengage Learning; 2010.

20. Sadock BJ, Sadock VA. Kaplan \& Sadock Buku Ajar psikiatri Klinis. Jakarta: EGC Kedokteran; 2014.

21. Sofia A. Battistini Garcia;, Guzman N. Acquired Immune Deficiency Syndrome (AIDS) CD4+ Count [Internet]. Treasure Island (FL) United States: StatPearls Publishing Copyright (C) 2020, StatPearls Publishing LLC.; 2020. Available from: https://www.ncbi.nlm.nih.gov/books/NBK513289/

22. IOM (Institute of medicine). HIV and disability: Updating the social security listings. HIV and Disability: Updating the Social Security Listings. Washington,D.C: The National Academies Press; 2010. 1-200 p.

23. Bastaman HD. Logoterapi: Psikologi untuk menentukan makna hidup dan meraih hidup bermakna. Jakarta: Raya Grafindo Pusada; 2007.

24. Schultz D. Psikologi Pertumbuhan: Model-model Psikologi Sehat. Yogyakarta: Kanisius; 1997.

25. Purba R. Prosen pencarian makna hidup pada ODHA (Orang dengan HIV/AIDS). Universitas Katolik Soegijapranata Semarang; 2008.

26. Batthyany A, Netzer PR. Meaning in Life : Nature, Needs, and Myths. In: Meaning in positive and existensial psychology [Internet]. XVII. New York: Spinger Science+Business Media New York; 2014. p. 25-37. Available from: http://www.springer. com/9781493903078

27. Starck PL. Theory of Meaning. In: Middle Rage Theory for Nursing. Third Edit. New York: Springer Publishing Company, LLC; 2014. p. 87-108.

28. Stricker SM, Fox KA, Baggaley R, Negussie E, de Pee S, Grede N, et al. Retention in Care and Adherence to ART are Critical Elements of HIV Care Interventions. AIDS Behav. 2014;18:465-75.

29. WHO. Global helath Sector Strategy on HIV 20162021 Towards Ending AIDS [Internet]. Strategy o. Gevana: WHO Press; 2016. Available from: www. who.int

30. Bangsberg DR, Kroetz DL, Deeks SG. Adherenceresistance Relationships to Combination HIV Antiretroviral Therapy. Curr HIV/AIDS Rep. 2007;(4):65-72.

31. Bangsberg DR. Less Than $95 \%$ Adherence to Nonnucleoside Reverse-Transcriptase Inhibitor Therapy Can Lead to Viral Suppression [Internet]. Vol. 43. 2006. Available from: http://cid. oxfordjournals.org/

32. Mukumbang FC, Belle S Van, Marchal B, Wyk B Van. Exploring ' generative mechanisms' of the antiretroviral adherence club intervention using the realist approach : a scoping review of researchbased antiretroviral treatment adherence theories. BMC Public Health. 2017;1-14. 